\title{
Platelet Indices in Neonates: A Comparative Study of Normal and Low Birth Weight Babies
}

\section{Tegsimran Duggal, Baljeet Maini, Gauri Chauhan, Bablu Kumar Gaur, Mukti Sharma And Anand Kumar Bhardwaj}

Department of Paediatrics, Department of paediatrics, MMIMSR, Mullana, Ambala, Haryana, India

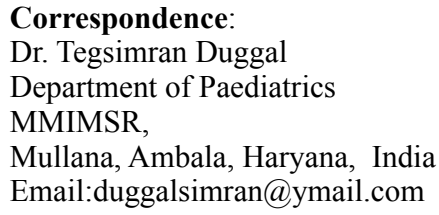

Mullana, Ambala, Haryana, India

Email:duggalsimran@ymail.com

DOI:10.3126/jnps.v39i1.21800

Submitted on: 2020-01-02

Accepted on: 2020-02-08

Acknowledgements: We acknowledge the institution management for allowing us to conduct this study as well as funding the laboratory investigations required for the purpose of this study.

Funding: Nil

Conflict of Interest: None declared

Permission form IRB: Yes

To cite this article: Duggal T, Maini $\mathrm{B}$, Chauhan G, Gaur B K, Sharma M, Bhardwaj AK. Platelet indices in neonates: A comparative study of normal and low birth weight babies. J Nepal Paediatr Soc. 2019;39(1):35-41.

\begin{abstract}
Introduction: Birth weight is an important indicator of perinatal and neonatal outcome. Low birth weight (LBW) babies suffer from many problems in neonatal period and have more morbidity and mortality as compared to normal weight babies. Platelets play an important role in neonatal immunity. Platelet indices of LBW babies are not well understood and may have contributed to morbidities in these babies. This study was conducted to study the platelet indices in LBW babies.
\end{abstract}

Methods: All inborn LBW babies born in our centre and fulfilling the inclusion criteria were enrolled in the study. Study period was of one and half years (Oct 2015 - Apr 2017). Cord blood sample (2 ml) was collected and platelet indices namely Platelet Count (PC), Mean Platelet Volume (MPV), Platelet Distribution Width (PDW), were assessed. Blood sample was processed with a hospital laboratory based automated analyser. Neonatal morbidities were recorded. Platelet indices were analysed with respect to low birth weight.

Results: The platelet count in LBW babies was lower than the control group. Other indices i.e. PDW and MPV however did not show significant variation between both the groups.

Conclusions: LBW babies had lower platelet counts but other platelet indices were not significantly affected. The results need to be substantiated with further larger studies in the future.

Key words: Low birth weight; newborn; platelet indices 


\section{INTRODUCTION}

As per World Health Organisation (WHO), low birth weight (LBW) is defined as weight of less than 2500 grams at birth. ${ }^{1}$ These include both preterm and term (small for gestational age) babies. Incidence of LBW babies is as high as $28 \%$ of all babies born in India (six to eight million) per year. ${ }^{2}$

Weight at birth is an important indicator of any unfavourable perinatal and neonatal outcome. Low birth weight babies suffer from many problems such as birth asphyxia, hypoglycemia, hypothermia, respiratory distress and develop infections very rapidly as compared to normal weight babies. $^{3}$ It is observed that LBW is responsible not only for about $50 \%$ of perinatal deaths and about $30 \%$ of infant deaths but also for early development of adulthood morbidities. ${ }^{4}$

Platelets have important role to play in achieving haemostasis, maintaining blood vessel integrity and for phagocytosis. In newborns, haemostasis is an ongoing process which goes on throughout the foetal period into early childhood. ${ }^{5}$ Those neonates who suffer from impaired immunity also have impaired haemostasis. ${ }^{5}$ It has been documented in literature that in addition to platelet count (PC), other platelet indices are also useful in predicting the onset of various neonatal morbidities at an earlier stage. Platelet distribution width (PDW) represents the degree of heterogeneity of platelets. The changes in PDW are the results from recruitment of multiple ploidy classes of megakaryocytes during rapid platelet production. An increased proportion of higher ploidy classes increases megakaryocyte heterogeneity. Mean platelet volume (MPV) is also a machine calculated value on routine coulter reports. Increased production of platelets causes increased MPV. ${ }^{6}$ It has been documented that thrombocytes also have a vital role to play as a participant in immune responses or as a part of developmental process of thrombosis. ${ }^{7,8}$

Multiple disease process can cause neonatal thrombocytopenia and this can be early onset thrombocytopenia (less than 72 hours) or late onset thrombocytopenia (more than 72 hours). ${ }^{9}$ About $17 \%$ to $30 \%$ of newborns who are in NICU are seen to suffer from thrombocytopenia ${ }^{10}$ and although the risk is more in LBW babies, it is greater in the most preterm infants i.e. in those with lesser gestational age. ${ }^{10,11}$ This study was an attempt to observe the effect of LBW with regard to clinical profile as well as haematological profile of platelet indices. This study was aimed to compare clinical profile of normal and LBW babies and to compare platelet indices of normal and low birth weight babies.

\section{METHODS}

This study was an observational comparative study conducted over a period of one and a half year (October 2015 to April 2017). It was conducted in neonatal division of a tertiary care hospital in North India. Prior ethical approval was taken from institute ethics committee before the start of study. Small for gestational age was defined as weight less than $10^{\text {th }}$ percentile according to gestational age. ${ }^{2}$ Period of gestation was calculated from the first day of last menstrual period. All inborn LBW babies except those fulfilling exclusion criteria were enrolled in the study. Babies excluded from study were those having birth asphyxia, born to mothers on non steroid anti inflammatory drugs, specific drugs of antiplatelet action or babies born with major congenital malformations, mothers having TORCH group of infections, infants of HIV positive mothers, mothers having thrombocytopenia of any cause in the last 15 days prior to delivery, mothers having conditions like idiopathic thrombocytopenic purpura, mothers having chorioamnionitis and newborns whose parents did not give consent. Based on an earlier study, ${ }^{6}$ assuming 90\% power (with level of significance to be $5 \%$ ), sample size calculated was 35 in each group (i.e. normal birth weight and low birth weight). Considering possible loss of some of the sample size due to various reasons, the number of babies for the study was kept to 45 in each group. Thus a minimum of 90 babies were recruited for this study. An electronic weighing machine, Phoenix Medical Systems (P) Ltd, BWS101, May, 2015, Tamil Nadu, India was used to measure the weight of the newborn. The base of the machine was hard, baby was fully unclothed (diaper also) and the weight was taken preferably before feeds, under all aseptic conditions. Blood was collected after the cutting of the umbilical cord. The primary volume of $0.5 \mathrm{ml}$ was disposed off to keep away from platelet activation. The next part of blood was collected in haematological tubes with 
anticoagulant potassium edetate $\left(\mathrm{K}_{2}\right.$ EDTA). PC, MPV and PDW were assessed. Blood sample was analysed with a hospital laboratory based automated haematology analyser- SYSMEXXP100 (XP series), Japan. Information regarding maternal profile was retrieved from maternal records and entered in the neonatal case sheet. All the neonatal morbidities were noted from the neonatal case records and the data were entered into Microsoft excel worksheet. In this study, data of clinical profile and platelet indices of cord blood of LBW babies were compared with those of normal weight babies. Follow up of these babies was not the part of this study.

Data was presented in frequency, percentage, mean, standard deviation etc. Normality of data was checked and statistical tests were applied accordingly. Student's t test and ANOVA tests were applied for continuous variables having normalised data, whereas Mann Whitney U and Kruskal-Wallis tests for the non-normalised data. Categorical data and proportions were analysed by Chi-square, Fisher exact and Yates correction tests as and wherever applicable. Statistical analysis was performed using SPSS 20.0 statistical program (Chicago, IL, USA). Values of $\mathrm{p}<0.05$ were considered significant. Descriptive statistics were given as mean and standard deviation (SD) or median: categorical variables were given as values and percentages.

\section{RESULTS}

A total of 45 babies with birth weight of $<2500$ grams were taken as cases and they were compared with 45 controls ( $>2500$ grams birth weight). In this study of 90 newborns, gestational age of newborns ranged from 28 weeks to 43 weeks of gestational age, (overall mean \pm 2 SD 36.08 weeks \pm 3.21 weeks). The mean gestational age of cases was 33.6 weeks (range 28-38 weeks) and that of controls was 37.8 weeks (range 34 to 43 weeks). Birth weight ranged from 906 grams to 4500 grams, (mean $\pm 2 \mathrm{SD}=2344 \pm 749$ grams). The mean birth weight of cases was $1.75 \mathrm{~kg}$ (range $0.906-2.434 \mathrm{~kg}$ ) while that of controls was 2.94 $\mathrm{kg}$ (range 2.52 to $4.5 \mathrm{~kg}$ ). Sixty one out of 90 newborns were born to primigravida mothers. (Table 1)
Table 1. Demographic profile of study patients

\begin{tabular}{|c|c|c|}
\hline S. No & Profile & $\begin{array}{l}\text { Descriptive } \\
\text { statistics }\end{array}$ \\
\hline \multirow[t]{3}{*}{1} & \multicolumn{2}{|c|}{ Gestation age (weeks) } \\
\hline & Range & $28-43$ \\
\hline & Mean \pm SD & $36.08 \pm 3.219$ \\
\hline \multirow[t]{2}{*}{2} & \multicolumn{2}{|l|}{ Gender } \\
\hline & Male : Female & $50: 40$ \\
\hline \multirow[t]{3}{*}{3} & \multicolumn{2}{|c|}{ Birth Weight (Kg) } \\
\hline & Range & $0.906-4.500$ \\
\hline & Mean \pm SD & $2.344 \pm 0.749$ \\
\hline \multirow[t]{2}{*}{4} & \multicolumn{2}{|l|}{ Parity } \\
\hline & Primi : Multi & $61: 29$ \\
\hline
\end{tabular}

In our study population, various morbidities of newborns were compared between normal and low birth weight babies. Among cases, 25 (55.6\%) had hyperbilirubinemia requiring phototherapy, whereas in control group $19(42.2 \%)$ had hyperbilirubinemia. Seven (15.6\%) newborns among cases had hypoglycemia whereas four $(8.9 \%)$ newborns had the same morbidity amongst controls. Hypocalcemia was observed among the 13 cases $(28.9 \%)$ whereas in control group five (11.1\%) newborns. Hypothermia was noted in four (8.9\%) newborns among cases and three (6.7\%) amongst the control group. Among the cases 10 babies had apnea (22.2\%), whereas in control group one $(2.2 \%)$ had apnea. Respiratory distress syndrome was noted in five newborns in this study all of them being low birth weight babies. Pneumonia was diagnosed in 26 newborns, out of which $15(33.3 \%)$ were among the cases and 11 $(24.4 \%)$ were among the control groups. Ten newborns in our study developed intraventricular haemorrhage (IVH); all the 10 newborns having IVH were from the case group accounting for $22.2 \%$. In this study, seven out of 90 newborns developed NEC during their stay in NICU; all the newborns who developed this clinical morbidity were from the case group $(15.6 \%)$ whereas none were noted in the control group. Overall, 20 newborns had meningitis. Among cases 13 (28.9\%) newborns had meningitis, in control group seven 
Table 2. Profile of neonatal morbidities in study patients

\begin{tabular}{|c|c|c|c|c|c|c|c|}
\hline \multirow[t]{2}{*}{ Complications } & \multirow[t]{2}{*}{$\mathbf{N}$} & \multirow{2}{*}{$\begin{array}{l}\text { Case } \\
\mathrm{F}\end{array}$} & \multirow{2}{*}{$\begin{array}{c}(\mathrm{n}-45) \\
\%\end{array}$} & \multicolumn{2}{|c|}{ Control (n-45) } & \multirow[t]{2}{*}{$X^{2}$} & \multirow[t]{2}{*}{ p-value } \\
\hline & & & & $\mathrm{F}$ & $\%$ & & \\
\hline $\begin{array}{l}\text { Hyperbillirubinemia } \\
\text { requiring phototherapy }\end{array}$ & 44 & 25 & 55.6 & 19 & 42.2 & 1.601 & 0.292 \\
\hline Hypoglycaemia & 11 & 7 & 15.6 & 4 & 8.9 & 0.932 & 0.522 \\
\hline Hypocalcemia & 18 & 13 & 28.9 & 5 & 11.1 & 4.444 & 0.063 \\
\hline Hypothermia & 7 & 4 & 8.9 & 3 & 6.7 & 0.155 & 1.000 \\
\hline Apnea & 11 & 10 & 22.2 & 1 & 2.2 & 8.399 & 0.007 \\
\hline RDS/HMD & 5 & 5 & 11.1 & 0 & 0.0 & 3.388 & 0.066 \\
\hline Pneumonia & 26 & 15 & 33.3 & 11 & 24.4 & 0.865 & 0.486 \\
\hline IV hemorrhage & 10 & 10 & 22.2 & 0 & 0.0 & 11.250 & 0.001 \\
\hline NEC & 7 & 7 & 15.6 & 0 & 0.0 & 5.577 & 0.018 \\
\hline Meningitis & 20 & 13 & 28.9 & 7 & 15.6 & 2.314 & 0.204 \\
\hline Sepsis & 49 & 33 & $73.3 \%$ & 16 & 35.6 & 12.947 & 0.001 \\
\hline
\end{tabular}

(15.6\%) had meningitis. There was no significant difference between the cases and controls in relation to meningitis. Out of 90 babies, sepsis was seen in 49 babies. Thirty three (73.3\%) septic babies belonged to low birth weight group, in the control group $16(35.6 \%)$ had sepsis. Overall, among the various neonatal morbidities studied, there were significant differences found in apnea, IVH, NEC, and sepsis among the cases and controls. (Table 2)

Table 3. Assessment of platelet indices in both groups

\begin{tabular}{|c|c|c|c|c|c|}
\hline \multirow{2}{*}{$\begin{array}{l}\text { Parame } \\
\text { ter }\end{array}$} & \multicolumn{2}{|c|}{ Case (n-45) } & \multicolumn{2}{|c|}{ Control (n-45) } & \multirow{2}{*}{$\begin{array}{l}\text { p- } \\
\text { value } \\
\text { a }\end{array}$} \\
\hline & $\begin{array}{l}\text { Media } \\
n\end{array}$ & $\begin{array}{l}\text { Mean } \\
\pm \mathrm{SD}\end{array}$ & $\begin{array}{l}\text { Media } \\
\mathrm{n}\end{array}$ & $\begin{array}{l}\text { Mean } \pm \\
\text { SD }\end{array}$ & \\
\hline $\begin{array}{l}\text { Platelet } \\
\text { count } \\
\text { (lakh/ } \\
\text { cu mm) }\end{array}$ & 1.80 & $\begin{array}{l}1.74 \pm \\
0.8041 \\
3.1\end{array}$ & 1.90 & $\begin{array}{l}1.95 \pm \\
0.82227 \\
.4\end{array}$ & 0.184 \\
\hline $\begin{array}{l}\text { PDW } \\
(\%)\end{array}$ & 11.5 & $\begin{array}{l}11.7 \pm \\
2.9\end{array}$ & 11.1 & $\begin{array}{l}11.2 \pm \\
2.5\end{array}$ & 0.383 \\
\hline $\begin{array}{l}\text { MPV } \\
\text { (fl) }\end{array}$ & 10.0 & $\begin{array}{l}9.8 \pm \\
1.5\end{array}$ & 9.8 & $\begin{array}{l}9.6 \pm \\
2.4\end{array}$ & 0.617 \\
\hline
\end{tabular}

(a) - Mann Whitney
In this study, platelet indices were compared between cases and controls. There was no significant difference of various platelet indices (PC, MPV, PDW) between cases and controls (table 3). In our study, 90 newborns were categorised under birth weight $<1000$ grams, $1000-1499$ grams, $1500-2499$ grams and $\geq 2500$ grams. There was a decreasing trend of platelet count was observed with decreasing birth weight, but this was

Table 4. Mean distribution of platelet count according to birth weight of neonates

\begin{tabular}{|c|c|c|c|c|}
\hline $\begin{array}{l}\text { Birth } \\
\text { weight }\end{array}$ & $\mathbf{N}$ & $\begin{array}{l}\text { Platelet } \\
\text { Count } \\
\text { Mean } \pm \\
\text { sd }\end{array}$ & $\begin{array}{l}\text { PDW } \\
\text { Mean } \pm \\
\text { sd }\end{array}$ & $\begin{array}{l}\text { MPV } \\
\text { (fl) } \\
\text { Mean } \pm \\
\text { sd }\end{array}$ \\
\hline $\begin{array}{l}<1000 \\
\text { grams }\end{array}$ & 3 & $\begin{array}{l}1.08 \\
\pm 0.13\end{array}$ & $\begin{array}{l}10.6 \% \\
\pm 1.8\end{array}$ & $9.7 \pm 1.6$ \\
\hline $\begin{array}{l}1000-1499 \\
\text { grams }\end{array}$ & 14 & $\begin{array}{l}1.58 \pm 0.5 \\
2\end{array}$ & $\begin{array}{l}12.0 \% \\
\pm 3.3\end{array}$ & $\begin{array}{l}10.1 \\
\pm 1.5\end{array}$ \\
\hline $\begin{array}{l}1500-2499 \\
\text { grams }\end{array}$ & 28 & $\begin{array}{l}1.90 \pm 0.8 \\
3\end{array}$ & $\begin{array}{l}11.6 \% \\
\pm 2.9\end{array}$ & $9.7 \pm 1.5$ \\
\hline $\begin{array}{l}\geq 2500 \\
\text { grams }\end{array}$ & 45 & $\begin{array}{l}1.95 \pm 0.8 \\
2\end{array}$ & $\begin{array}{l}11.2 \% \\
\pm 2.5\end{array}$ & $9.6 \pm 2.4$ \\
\hline P value* & 0.296 & 0.701 & 0.882 & \\
\hline
\end{tabular}

*Kruskal-Wallis Test 
not significant statistically (table 4) although there was no significant difference of PDW and MPV between the various birth weight categories.

\section{DISCUSSION}

In this study, LBW babies were largely preterm and term small for date babies. In the normal weight group, almost all of them, were $>34$ weeks gestational age. Neonates suffered from various morbidities. Morbidities like neonatal jaundice, hypoglycemia, hypocalcaemia, hypothermia were not different statistically in low birth weight babies. It seems in contrast to old literature where LBW has been a risk factor for all these issues. These findings possibly relate to be the result of improved neonatal care in a tertiary care hospital. Morbidities like respiratory distress syndrome (RDS), apnea of prematurity, pneumonia, meningitis and sepsis were more in LBW group, in agreement with earlier studies. There was significantly prolonged stay in NICU and duration of antibiotics use in LBW babies as also the problems of intraventricularhaemorrhage and necrotising enterocolitis, similar to available literature. ${ }^{12-17}$

Platelet indices were analysed in relation to birth weight. In our study (based on birth weight difference), the PC in LBW babies was lower than the control group similar to another Indian study. ${ }^{18}$ Other indices i.e. PDW and MPV however did not show significant variation between both the groups. In another study from India, authors have shown a significant difference of PDW in both the groups. ${ }^{19}$ Belet et al. also concluded that PC and MPV don't differ significantly in term and preterm babies. ${ }^{20} \mathrm{~A}$ study in India showed that MPV of preterm were higher and PDW was also significantly increased in preterm compared to term neonates. ${ }^{21}$ Similarly in a study by Wasiluk et al., the platelet count was lower in pre-terms, PDW and MPV were significantly higher. ${ }^{22}$ Thus, there is no general agreement in these studies regarding platelet indices in the neonatal period. Moreover, these other studies, were based on gestational age difference (and not on birth weight difference).

The platelet indices were correlated with various sub-categories of birth weight (ELBW, VLBW, LBW and normal). This study though showed a trend of decrease in PC with decreasing birth weight, which was not found significant on statistical terms. It is to be considered that although our LBW babies groups, especially preterm babies, had lower platelet counts but did not cause any significant clinical problem of bleeding. All these parameters do reflect the immaturity of thrombopoiesis in newborn preterm infants. The western studies have more babies in extreme preterm and ELBW category. Also, the results may be influenced due to difference in the overall size of study groups.

In our study none of the indices showed any significant difference in normal and LBW babies among the septic neonates. Ahmad MS, and E Guclu et al. had findings of thrombocytopenia in LBW babies, and reported PDW as a uniquely significant parameter suggestive in severe sepsis. $^{23,24}$ As the number of patients with sepsis were small in our study, appropriate statistical interpretations would be difficult to comment upon.

\section{CONCLUSIONS}

This study was an attempt to observe the effect of LBW with regard to clinical profile as well as haematological profile of platelet indices. In this study we did find similarities with earlier literature with respect to the acute clinical implication of LBW. We did not find any significant impact of birth weight, gestational age and birth weight for gestation on various platelet indices, which is important as India faces a huge problem of LBW and small weight for gestational age. This study had very few babies less than 1000 grams birth weight. So the effect of extreme preemies may not be reflected in our study results. Number of babies with morbidities like RDS and IVH were lesser. The age at which platelet count became 'normal' in babies with low PC at birth, was not studied. The study is a relatively smaller study conducted in a single centre. More such multi-centric extensive studies with larger number of babies are thus recommended. 


\section{REFERENCES}

1. World Health Organisation, International statistical classification of diseases and related health problems, tenth revision, World Health Organisation, Geneva, 1992. Available at :https://www.who.int/classifications/icd/ICD10Volume2_en_2010.pdf. Accessed on $15 \mathrm{feb}, 2020$.

2. Singh M. Disorders of Weight and Gestation. In: Care of the Newborn. Meharban Singh(editor). $8^{\text {th }}$ ed. Delhi:Jain publications; 2015.p. 299-322.

3. Ramji S, Modi M and Gupta N, 50 Years of Neonatology in India. Progress and Future. Indian Pediatr. 2013;50:104-06. DOI: https://doi.org/10.1007/s13312-013-0023-2

4. Sisk PM, Lovelady CA, Dillard RG, Gruber KJ. Lactation counselling for mothers of very low birth infants; effect on maternal anxiety and infant of human milk. Pediatrics. 2006;117(5):1859-60. DOI:10.1542/peds.2005-0267

5. Maconi M, Rolfo A, Cardaropoli S, Brini M, Danise P. Haematologic values in healthy and small for gestational age newborns. Lab Hematol. 2005;11(2):152-6.DOI:10.1532/LH96.04076

6. Bessman JD, Williams LJ, Gilmer PR. Platelet Size In Health and Hematologic Disease. Am J ClinPathol. 1982;78:150-3. DOI: https://doi.org/10.1093/ajcp/78.2.150

7. Von Hundelshausen P, Weber C. Platelets as immune cells: bridging inflammation and cardiovascular disease. Circ Res. 2007;100(1):27-40. DOI:10.1161/01.RES.0000252802.25497.b7

8. Andrews RK, Berndt MC. Platelet adhesion: a game of catch and release. J Clin Invest. 2008.118(9):3009-11. DOI: 10.1172/ JCI36883

9. Forestiere F, Daffos F, Galacteros F. Haematological values of 163 normal foetuses between 18 and 30 weeks of gestation. Paediatrics. 1986.20:342-6. DOI:10.1203/00006450-198604000-00017

10. Kalpnan C, Morel kopp MC, Clemenceau S. Fetal and neonatal alloimmune thrombocytopenia. Transf Med. 1992;2:265-71.PMID: 23687553

11. McPherson RJ, Juul S. Patterns of thrombocytosis and thrombocytopenia in hospitalized neonates. J Perinatol. 2005;25:166-72. DOI https://doi.org/10.1038/sj.jp.7211230

12. Tudehope Di, Rogers Y. Clinical spectrum of neonatal apnoea in very low birthweight infants. J Paediatr Child Health. 1984;20(2):131-5. DOI: 10.1111/j.1440-1754.1984.tb00061.x

13. Hillier SL, Nugent RP, Eschenbach DA, Krohn MA, Gibbs RS, Martin DH, et al. Association between bacterial vaginosis and preterm delivery of a low- birth-weight infant. N Engl J Med. 1995;333(26):1737-42. DOI: 10.1056/NEJM199512283332604

14. Helwich E, Wojkowska-Mach J, Borszewska-Kornacka M, Gadzinowski J, Gulczynska E, Kordek A, et al. Epidemiology of infections in very low birth weight infants. Polish Neonatology Network research]. Med Wieku Rozwoj. 2013;17(3):224-31. PMID:24296446

15. Lemons JA, Bauer CR, Oh W, Korones SB, Papile LA, Stoll BJ, et al. Very low birth weight outcomes of the National Institute of Child health and human development neonatal research network, January 1995 through December 1996. NICHD Neonatal Research Network.Pediatrics. 2001;107(1):E1. DOI:10.1542/peds.107.1.e1

16. Krebs VL, Costa GA. Clinical outcome of neonatal bacterial meningitis according to birth weight. Arq Neuropsiquiatr. 2007;65(4 B):1149-53. DOI:10.1590/s0004-282x2007000700011

17. Numerato D, Fattore G, Tediosi F, Zanini R, Peltola M, Banks H, et al. Mortality and length of stay of very low birth weight and very preterm infants: A EuroHOPE study. PLoS One. 2015;10(6). DOI: 10.1371/journal.pone.0131685

18. Gupta A, Kumari S, Singhal A, Bahl A. Neonatal thrombocytopenia and platelets transfusion. Asian J Transfus Sci. 2012;6(2): 161. DOI: 10.4103/0973-6247.98924.

19. Sandeep M, Thammanna PS, Sridhar P V. Platelet Indices in Preterm Neonates : A Prospective Study. Int J Sci Stud. 2015;3(7):36. DOI: $10.17354 / \mathrm{ijss} / 2015 / 485$

20. Belet N, Kucukoduk R, Sancak S, UysalS. Perinatal asphyxia and thrombocytopenia. J Exp Clin Med. 1999;2:100-4. DOI: $10.4103 / 2249-4847.140399$

21. Alva PSR, Ashwini KT, Navya BN. Comparative Study of Platelet Indices between Term , Preterm and Small for Gestational Age Newborns Platelet count in SGA, Preterm and Term newborn. Sch. J. App. Med. Sci.2016;4:3985-9. DOI: 10.21276/sjams. 2016.4.11.25

22. Wasiluk A, Osada J, Dabrowska M, Szczepański M, Jasinska E. Does prematurity affect platelet indices? Adv Med Sci. 2009;54(2):253-5. DOI: 10.2478/v10039-009-0034-3.

23. Ahmad MS, Waheed A. Platelet counts, MPV and PDW in culture proven and probable neonatal sepsis and association of platelet counts with mortality rate. J Coll Physicians Surg Pak. 2014;24(5):340-4. DOI: 04.2014/JCPSP.340344. 
24. Guclu E, Durmaz Y, Karabay O. Effect of severe sepsis on platelet count and their indices. Afr Health Sci. 2013;13(2):333-8. DOI:10.4314/ahs.v13i2.19 